\title{
On the Cause and Prevention of Tundish Nozzle Clogging
}

\author{
W.F. Caley \\ Department of Process Engineering and Applied Science \\ Dalhousie University, Halifax, NS, Canada B3J2X4
}

(Received March 22,2006; final form March 31,2006)

\begin{abstract}
The formation of accretions or clogging of tundish nozzles in the continuous casting of steel is detrimental both to caster productivity and to eventual inclusion content of the final product. The cause of the clogging is related to a combination of operating criteria including ladle slag practice, tundish refractory, deoxidation methodology and temperature. To assess the effect of various slag components on clogging a mineralogical and rheological study was conducted on both plant and simulated accretion material.

Minerals belonging to the lime-alumina-silica system such as hibonite, gehlenite, mullite, spinel and corundum, all having solidification temperatures at or above steelmaking temperatures, were most prevalent. In Mn-rich melts larnite, hibonite and a glassy phase were predominant. The rheological studies confirmed the formation of a significant solids fraction near steelmaking temperatures for basic melts whereas high ( $>30 \mathrm{w} / \mathrm{o}$ ) Mn melts were glassy. As well, the plate composition of the gating system was also deemed to contribute to the problem, with $\mathrm{ZrO}_{2}$ being preferable to $\mathrm{Al}_{2} \mathrm{O}_{3}$. Results are discussed with a view to designing tundish slags to minimise formation of refractory solids while maintaining reasonable compatibility with refractory and gating system practice.
\end{abstract}

\section{INTRODUCTION}

The clogging of nozzles, both from ladle to tundish and from tundish to caster, has long been problematic with respect to maintaining a constant, reliable flow of inclusion-free steel. Of the two, restricted flow through slide gating systems that lead steel from tundish to strands is perhaps more concerning because this represents final slag and steel chemistry and is a continuous process rather than the batch type of situation associated with the ladle. Many contributors to clogging have been identified and discussed, both from the industrial perspective and through laboratory studies. For example, the use of aluminum as a deoxidiser has been linked to formation of various aluminates, both as accretions $/ 1,2 /$ and as inclusions in the final product $/ 3-5 /$. As well, silicon killed steels have been noted to enhance clogging often leading to an operator choosing to increase the oxygen content of the steel in the tundish. This latter approach would necessarily lead to enhanced slag formation, a change in slag chemistry and subsequently would increase the possibility of forming inclusions that could be carried into the steel product. Any slag carried from ladle to tundish will blend with the tundish thermal blanket, or flux if used, to give a tundish slag that must be chemically compatible with both the refractory and the nozzle/gating system. This final slag must also be relatively fluid at steelmaking temperatures to ensure that any refractory minerals formed are readily retained by the slag and do not become entrained in the metal phase. Finally, measurement and control of the temperature of the tundish metal/slag melt has been variously identified as being important to restrict buildup of accretions in a gating system $/ 6 /$. 
In previous works by the author and others, synthetic ladle slags based on the lime-alumina-silica (CAS) and magnesia-lime-alumina-silica systems were prepared to investigate the possibility of replacing all or part of the main fluxing material, fluorspar, with relatively inexpensive industrial minerals. These works addressed both rheological and mineralogical aspects and included studies on using feldspar/feldspathoid minerals $/ 7-9 /$, as well as a barite/fluorite ore and asbestos tailings, the latter taken from an asbestos mine in Newfoundland and Labrador, Canada /10/. Pertinent findings were that, aside from fluorspar-containing slags best slag fluidity was attained by replacing fluorspar with nepheline syenite, a feldspathoid tailing material that contained mainly silica, alumina and alkalis. Best mineralogy regarding presence of refractory minerals was also attributed to a nepheline syenite slag whereby the final mineral assemblage consisted of pseudowollastonite (m.pt. 1623K) with lesser amounts of merwinite (m.pt. $1723 \mathrm{~K})$. This may be compared to melts containing higher levels of $\mathrm{CaO}$ and $\mathrm{MgO}$ whereby merwinite and monticellite (m.pt. 1758K) predominated.

Bearing in mind that some portion of ladle slag is usually carried over to tundish, the previous studies were extended to investigate the influence of such carryover on tundish slag compesition and eventually to formation of accretions in gating systems and/or a submerged entry nozzle (SEN). Slags modelled after the CAS system were used to simulate the mineralogy and fluidity in a tundish. Again, nepheline syenite as a fluorspar replacement tended to avoid the formation of refractory di- and tricalcium silicates, with the lower melting point mineral pseudowollastonite predominating $/ 11 /$. Finally, in a subsequent work the plates from a three-plate slide gate system (two fixed $\mathrm{Al}_{2} \mathrm{O}_{3}$, one $\mathrm{ZrO}_{2}$ slide plate) were removed from service and examined for accretion mineralogy /12/. Findings suggested that the plate composition also had a bearing on extent of clogging with $\mathrm{ZrO}_{2}$ being preferable.

The present work is intended to build on findings from the previous research cited. In particular, it involves a mineralogical and rheological study of simulated ladle and tundish slags, with compositions modelled from industrial sampling to both determine factors most responsible for accretion formation and to propose a method for prevention.

\section{MATERIALS AND METHODS}

\subsection{Plant Scale Slag Sampling}

To provide a reasonable starting point for preparation of a synthetic slag for laboratory work slag samples were drawn from a typical mini mill that consisted of an electric arc furnace (EAF) with ladle arc refining (LRF) and tundish leading to a five strand continuous caster. Plates in the gating system consisted of alumina with a zirconia insert as working lining. Sampling of slag was conducted by dipping one of a temperature probe or $\mathrm{O}_{2}$ lance into $\mathrm{EAF}$, ladle and tundish melts as appropriate thereby freezing some slag on the rod. To check for possible compositional difference by depth a series of tundish samples was also drawn from three different depths. In this way an estimate of tundish slag composition at "top", "middle" and "bottom" was obtained. The resulting bulk chemical analyses, obtained using wet chemical techniques, are given in Table 1. Only major components and those deemed to be important for this work are presented. In addition, selected values obtained from a previous work /11/ are included for comparison purposes. Finally, to assess reaction with nozzle/plates, sets of gating systems were obtained after use and cored using a diamond core drill.

Table 1

Summary of bulk slag analyses from EAF, ladle and tundish, mass $\%$

\begin{tabular}{|l|l|l|l|l|l|l|}
\hline Location & $\mathrm{CaO}$ & $\mathrm{Al}_{2} \mathbf{O}_{3}$ & $\mathrm{SiO}_{2}$ & $\mathrm{MgO}$ & $\mathrm{MnO}$ & $\mathrm{FeO}$ \\
\hline EAF & 48.2 & 8.7 & 13.8 & 12.5 & 4.1 & 9.6 \\
\hline Ladle & 60.4 & 2.8 & 18.9 & 7.5 & 1.0 & 7.0 \\
\hline $\begin{array}{l}\text { Tundish } \\
\text { (top) }\end{array}$ & 1.4 & 3.4 & 39.3 & 9.4 & 31.0 & 11.0 \\
\hline $\begin{array}{l}\text { Tundish } \\
\text { (middle) }\end{array}$ & 1.4 & 2.7 & 38.5 & 10.3 & 33.9 & 11.3 \\
\hline $\begin{array}{l}\text { Tundish } \\
\text { (bottom) }\end{array}$ & 1.3 & 3.0 & 40.4 & 10.0 & 33.0 & 11.5 \\
\hline $\begin{array}{l}\text { Tundish } \\
\text { (ref. 11) }\end{array}$ & 13.8 & 3.3 & 50.5 & 7.2 & 13.4 & 8.7 \\
\hline
\end{tabular}

\subsection{Laboratory Slag Preparation}

Based on the analyses of the industrial slags (Table 
1), laboratory or model slags were prepared for rheological testing and mineralogical analysis. Use of model slags was necessary because industrial slag samples, when remelted in a laboratory environment, do not retain their original chemistry and the resulting compositions generally require temperatures in excess of normal steelmaking temperatures (1873-1923K) to attain a melt.

In previous works where the intent was to assess the influence of slag carryover on tundish slag rheology and final mineral assemblage $/ 11,12 /$ the CAS system was chosen to simulate the slags. However, in the present work, because of the high levels of $\mathrm{MnO}$ found in the tundish, two model slags were prepared by mixing stoichiometric blends of reagent grade $\mathrm{CaO}, \mathrm{SiO}_{2}, \mathrm{FeO}$ and $\mathrm{MnO}_{2}$ as appropriate to simulate ladle and tundish melts. Table 2 presents a summary of the slags; selected

Table 2

Composition of laboratory slags (mass\%, as prepared)

\begin{tabular}{|l|l|l|l|l|l|l|}
\hline SLAG & $\mathrm{CaO}_{2}$ & $\mathrm{Al}_{2} \mathrm{O}_{3}$ & $\mathrm{SiO}_{2}$ & $\mathrm{MgO}$ & $\mathrm{MnO}$ & $\mathrm{FeO}$ \\
\hline Ladle & 40.0 & & 50.0 & & & 10.0 \\
\hline Tundish & & & 41.0 & 13.0 & 26.0 & 13.0 \\
\hline $\begin{array}{l}\text { Tundish } \\
\text { (standard } \\
\text { carryover/11/) }\end{array}$ & 41.5 & 7.4 & 51.1 & & & \\
\hline $\begin{array}{l}\text { Tundish (low } \\
\text { carryover/11/) }\end{array}$ & 26.0 & 5.7 & 68.4 & & & \\
\hline $\begin{array}{l}\text { Tundish (high } \\
\text { carryover/11/) }\end{array}$ & 51.9 & 7.1 & 41.0 & & & \\
\hline
\end{tabular}

tundish blends based on the CAS system /11/ are also included in the table for comparison purposes. The mixtures for the present work were chosen to be a best compromise between industrial reality and a blend that was liquid at $1873 \mathrm{~K}$. All mixtures were dried (723K, $24 \mathrm{~h}$ ), mixed in a ball mill for $1 \mathrm{~h}$ with 10 drops of a 50/50 mixture of acetic acid and methanol to avoid agglomeration and pressed (133 $\mathrm{MPa}, 2 \mathrm{~min}$.) using a Loomis cold isostatic press. To examine crucible/melt reactivity, small test samples $(10 \mathrm{~g})$ were placed in $\mathrm{Al}_{2} \mathrm{O}_{3}, \mathrm{MgO}$ and $\mathrm{ZrO}_{2}$ crucibles as appropriate, heated to $1873 \mathrm{~K}$ for $1 \mathrm{~h}$ and sectioned.

\subsection{Slag Rheology}

To assess the rheological behaviour of each melt a $50 \mathrm{~g}$ sample of each slag was added to a $50 \mathrm{cc}$ working crucible and placed in a Lucifer Melt Master elevator furnace. The experimental process followed has been described elsewhere $17 /$. Briefly, the heating profile consisted of $1 \mathrm{~h}$ to $1873 \mathrm{~K} ; 0.2 \mathrm{~h}$ at temperature, during which time a spindle was immersed and equilibrated; and $0.5 \mathrm{~h}$ controlled cooling to $1473 \mathrm{~K}$. The rotating spindle method was used to collect rheological data on cooling (Brookfield 1/4 RVT-RL-404 or Digital model DV II, Strawberry Tree ${ }^{I M}$ acquisition system). The viscometer/spindle ( $\mathrm{MgO}$ or $\mathrm{Al}_{2} \mathrm{O}_{3}$ ) assemblage was calibrated using a series of six Brookfield standard silicon oils. After cooling, representative slag/crucible samples were sectioned using a diamond wafer saw pending metallographic polishing and mineralogical examination using EPMA.

\subsection{Mineralogical Characterisation}

To provide an estimate of potential for clogging to occur, the mineralogy for each slag given in Tables 1 and 2 along with associated melting points were determined using electron probe microanalysis (EPMA, JEOL Superprobe, $15 \mathrm{kV}, 15 \mathrm{~mA}$ beam current). Prior to analysis, $0.025 \mathrm{~m}$ dia. polished sections were prepared by mounting samples in cold mount epoxy, grinding through 600 grit $\mathrm{SiC}$ and polishing to a $0.25 \mu \mathrm{m}$ finish with diamond paste. Where appropriate polished sections of cored samples taken from gating systems, after removal from service, were similarly prepared for EPMA analysis.

\section{RESULTS}

\subsection{Mineralogical (EPMA) Considerations- Industrial Slags}

The EPMA analyses for representative samples of ladle and tundish slags are given in Table 3. Suggested mineralogy and approximate melting points drawn from Reference /13/ are also included. Of particular note is the presence of hibonite and larnite in the ladle slag versus the almost completely amorphous nature of the tundish slag, other than minor occurances of a family of 
complex manganese silicates in the olivine family similar to rhodonite + fayalite.

Table 3

EPMA/mineralogical analyses for industrial ladle and tundish slags (mass \%)

\begin{tabular}{|l|c|c|c|c|c|c|c|c|c|}
\hline SLAG & $\mathrm{CaO}$ & $\mathrm{Ai}_{2} \mathbf{O}_{3}$ & $\mathbf{S i O}_{2}$ & $\mathrm{MgO}$ & $\mathrm{MnO}$ & $\mathbf{F e O}$ & $\mathrm{ZrO}_{2}$ & Mineral & $\begin{array}{c}\text { Approx. } \\
\text { M.Pt. K } \\
/ 13 /\end{array}$ \\
\hline Ladle & 62.7 & 0.6 & 33.5 & 2.1 & 0.2 & 0.0 & 0.0 & larnite & 2400 \\
\hline Ladle & 3.5 & 93.5 & 2.7 & 0.2 & 0.0 & 0.1 & 0.2 & hibonite & 2123 \\
\hline Ladle & 52.1 & 24.2 & 6.0 & 1.2 & 0.8 & 12.6 & 1.2 & glass & 1950 \\
\hline Tundish & 0.8 & 5.5 & 38.6 & 6.6 & 38.5 & 5.2 & 4.1 & glass & 1570 \\
\hline Tundish & 1.3 & 10.5 & 40.2 & 1.9 & 30.2 & 8.9 & 6.4 & complex Mn silicate & 1574 \\
\hline
\end{tabular}

Table 4

EPMA/mineralogical analyses for slag interface of industrial tundish nozzles/plates removed from service (mass \%).

\begin{tabular}{|c|c|c|c|c|c|c|c|c|c|}
\hline SLAG & $\mathrm{CaO}$ & $\mathbf{A i}_{2} \mathbf{O}_{3}$ & $\mathrm{SiO}_{2}$ & MgO & MnO & $\mathbf{F e O}$ & $\mathbf{Z}_{\mathbf{r O}}$ & Mineral & $\begin{array}{c}\text { Approx. } \\
\text { M.Pt. K } \\
/ 13 /\end{array}$ \\
\hline Zirconia plate & & & 35.0 & 22.0 & 31.0 & 5.0 & 7.5 & glass & 1550 \\
\hline Zirconia plate & & & 40.0 & 5.0 & 35.0 & 7.0 & 5.0 & glass & 1550 \\
\hline Zirconia plate /12/ & 0.8 & 67.9 & 0.5 & 26.6 & & & trace & spinel & 2378 \\
\hline Zirconia plate /12/ & 41.7 & 36.1 & 21.1 & 0.4 & & & trace & gehlenite & 1866 \\
\hline Alumina plate /12/ & & 74.0 & 23.3 & 0.2 & & & & mullite & 2123 \\
\hline Alumina plate /12/ & 0.1 & 70.3 & 0.1 & 28.5 & & & & spinel & 2378 \\
\hline Alumina plate /12/ & 40.9 & 34.3 & 22.2 & 0.8 & & & & gehlenite & 1866 \\
\hline $\begin{array}{l}\text { Accretion on } \mathrm{Al}_{2} \mathrm{O}_{3} \\
\text { plate } / 12 /\end{array}$ & 9.3 & 80.1 & 8.2 & 1.6 & 0.8 & & & hibonite & 2123 \\
\hline
\end{tabular}

\subsection{Mineralogical (EPMA) Considerations- -Indüstrial Tündish Nozzles/Plates}

The EPMA analyses for representative gating systems removed from service are given in Table 4. Included are suggested minerals found at the zirconia plate/slag/metal working interface for the present work as well as selected data taken from previous work where both zirconia and alumina were in contact with slag/metal as part of a three-plate gating system $/ 11,12 /$. Of note is the glassy nature of the Mn-based slag and absence of refractory minerals for the zirconia plate in the present work versus the minor presence of aluminabased refractory minerals for zirconia in the previous work cited /12/. Also, whereas the zirconia liner/plates were not clogged, significant alumina-based accretions were found in the alumina plates $/ 12 \%$. Again, approximate melting temperatures are drawn from Reference /13/.

\subsection{Mineralogical (EPMA) Considerations- Laboratory Slags}

The EPMA analyses for laboratory ladle and tundish slags given in Table 2 for the present work are presented in Table 5. Ladle melts were contained in alumina crucibles whereas tundish slags were liquefied in both magnesia and zirconia crucibles. The identifying labels 
Table 5

EPMA/mineralogical analyses for laboratory ladle and tundish slags (mass\%).

\begin{tabular}{|c|c|c|c|c|c|c|c|c|c|}
\hline SLAG & $\mathrm{CaO}$ & $\mathbf{A i}_{2} \mathbf{O}_{3}$ & $\mathrm{SiO}_{2}$ & MgO & Mno & $\mathrm{FeO}$ & $\mathrm{ZrO}_{2}$ & Mineral & $\begin{array}{c}\text { Approx. } \\
\text { M.Pt. K } \\
/ 13 / \\
\end{array}$ \\
\hline $\begin{array}{l}\text { Ladle } / \mathrm{Al}_{2} \mathrm{O}_{3} \\
\text { Crucible } \\
\text { (A) }\end{array}$ & & 99.9 & & & & & & $\begin{array}{l}\text { alumina } \\
\text { crucible }\end{array}$ & $\mathbf{N} / \mathbf{A}$ \\
\hline (B) & 42.1 & 35.0 & 21.9 & & & 1.6 & & gehlenite & 1866 \\
\hline (C) & 23.3 & 58.4 & 11.3 & & & 7.6 & & glass & 1948 \\
\hline (D) & 45.3 & 4.3 & 40.4 & 0.23 & & 9.2 & & glass & 1623 \\
\hline $\begin{array}{l}\text { Tundish / MgO } \\
\text { Crucible } \\
\text { (E) }\end{array}$ & & & & 101.4 & & & & $\begin{array}{l}\text { magnesia } \\
\text { crucible }\end{array}$ & $\mathbf{N} / \mathbf{A}$ \\
\hline (F) & 0.3 & & 50.6 & 16.5 & 30.3 & 3.2 & & glass & 1725 \\
\hline (G) & & 0.2 & 11.1 & 6.7 & 32.6 & 47.9 & & glass & 1673 \\
\hline $\begin{array}{l}\text { Tundish } / \mathrm{ZrO}_{2} \\
\text { Crucible } \\
\text { (H) }\end{array}$ & 3.5 & & & 0.9 & & & 96.7 & $\begin{array}{l}\text { zirconia } \\
\text { crucible }\end{array}$ & N/A \\
\hline (J) & 1.9 & & 49.2 & 11.9 & 35.1 & 3.4 & & glass & 1695 \\
\hline (K) & & & & 0.5 & 2.2 & 1.2 & 98.3 & zirconia & 2950 \\
\hline
\end{tabular}

in Table 5 refer to locations where the analyses were taken. These are given in Figure 1 for a ladle melt/alumina crucible; Figure 2, tundish melt/magnesia

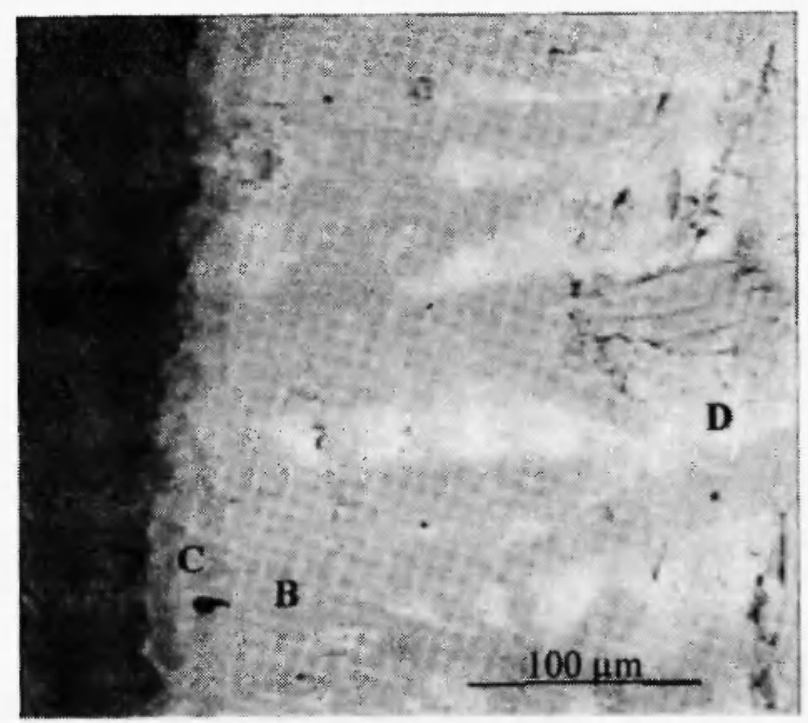

Fig. 1: Micrograph of ladle slag in $\mathrm{Al}_{2} \mathrm{O}_{3}$ crucible. EPMA analyses for crucible (A) and slag (B-D) are given in Table 5 . crucible and Figure 3, tundish melt/zirconia crucible. Not shown are results for tundish melt/alumina crucible due to extensive reaction. Of particular note is the

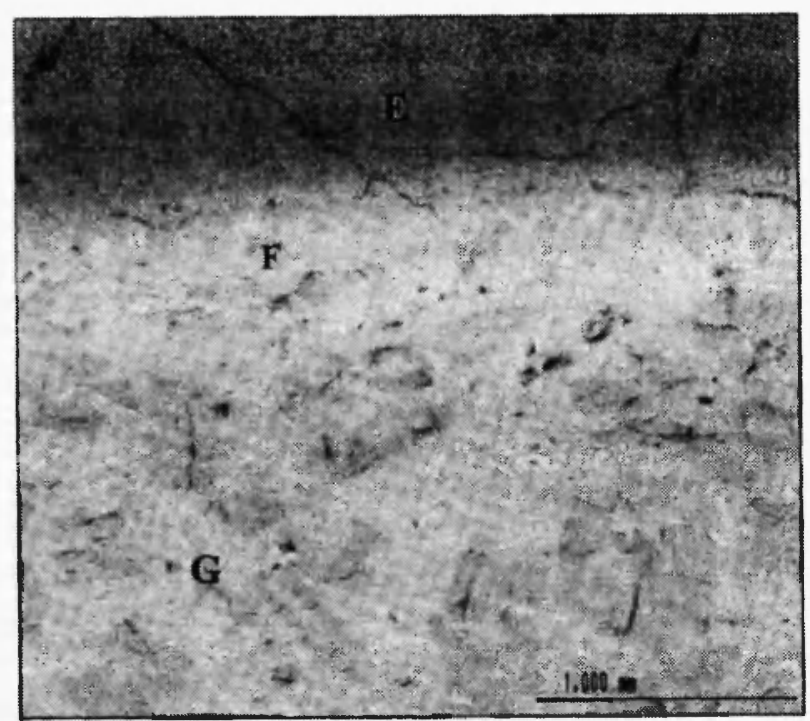

Fig. 2: Micrograph of tundish slag in $\mathrm{MgO}$ crucible. EPMA analyses for crucible $(E)$ and slag $(F, G)$ are given in Table 5 . 


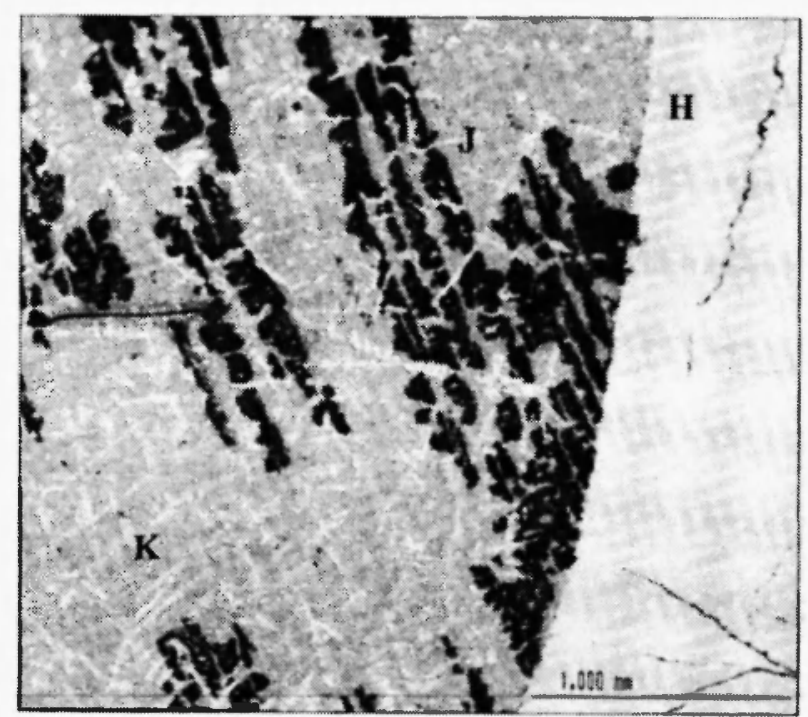

Fig. 3: Micrograph of tundish slag in $\mathrm{ZrO}_{2}$ crucible. EPMA analyses of crucible $(\mathrm{H})$ and slag $(\mathrm{J}, \mathrm{K})$ are given in Table 5 .

presence of the low melting point mineral gehlenite in the ladle slag along with a low melting point glass. In contrast the tundish slags were glassy, with presence of any mineralisation being beyond the resolution of the instrument.

\subsection{Rheological Considerations-Laboratory Slags}

Results for rheological testing of the laboratory ladle and tundish slags are given in Figures 4,5 (ladle) and 6,7 (tundish). In all cases plots of increase in apparent viscosity on cooling are given and represent data taken from two replicate experiments. The log viscosity vs reciprocal temperature plots in Figures 5 and 7 were included as an attempt to assess the presence/absence of a gel or crystallisation temperature for each slag. For the ladle slag this is estimated to be $1625 \mathrm{~K}$ whereas the tundish slag did not exhibit any obvious fixed gel point.

\section{DISCUSSION}

The major mineralisation reported for the experimental ladle slags, present work, (Table 5) included gehlenite along with two glasses. Of these, the gehlenite would be expected to crystallise at about $1866 \mathrm{~K}$ or slightly below steelmaking temperatures (1873-1923K). At these temperatures, the predominant glass phase would have been liquid whereas the other

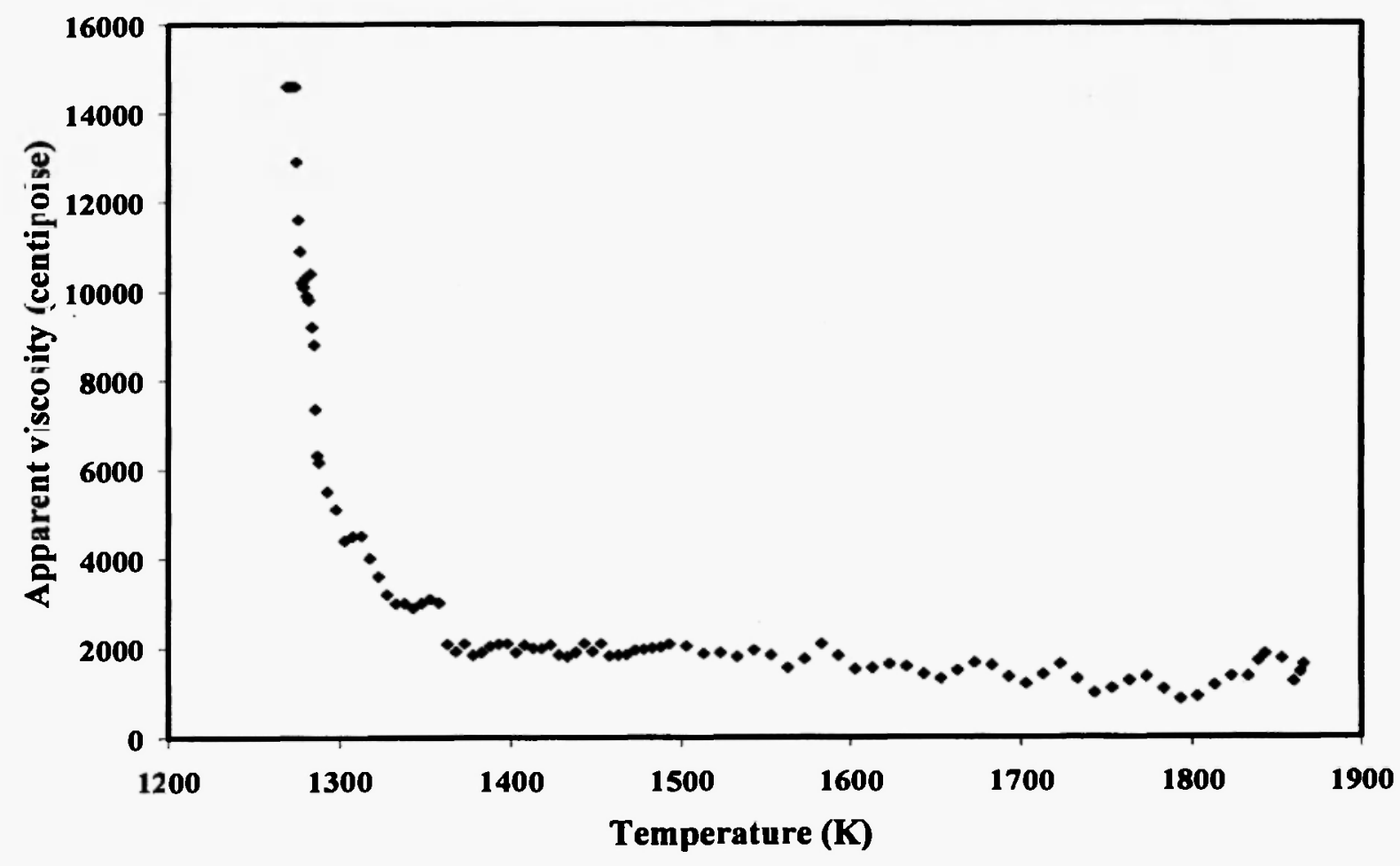

Fig. 4: Plot of apparent viscosity (cps or $\mathrm{mPa} . \overline{\mathrm{s}}$ ) as a function of temperature (K) for laboratory ladle slag. 


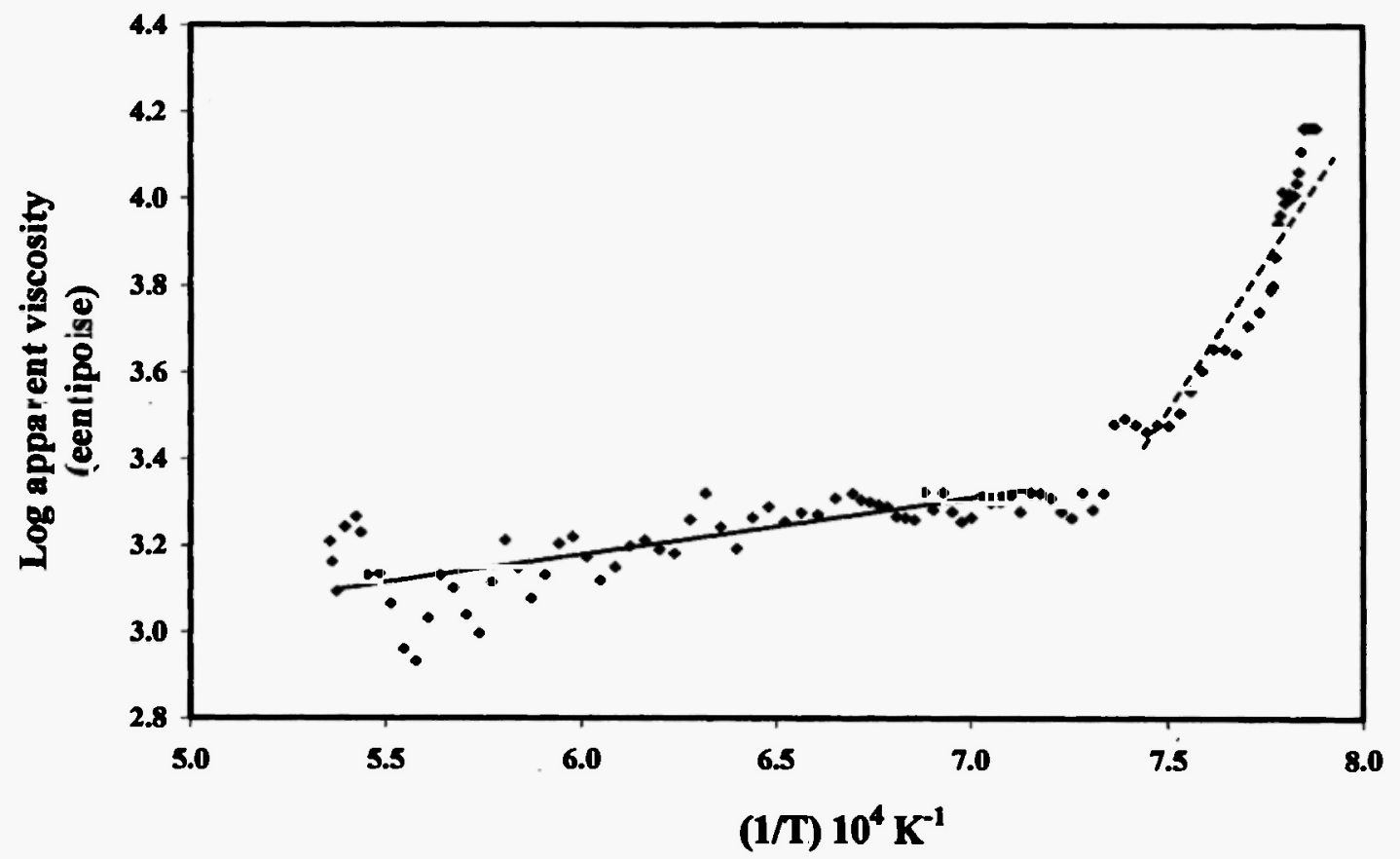

Fig. 5: Plot of log apparent viscosity (cps or mPa.s) as function of reciprocal temperature (K) for experimental ladle slag.

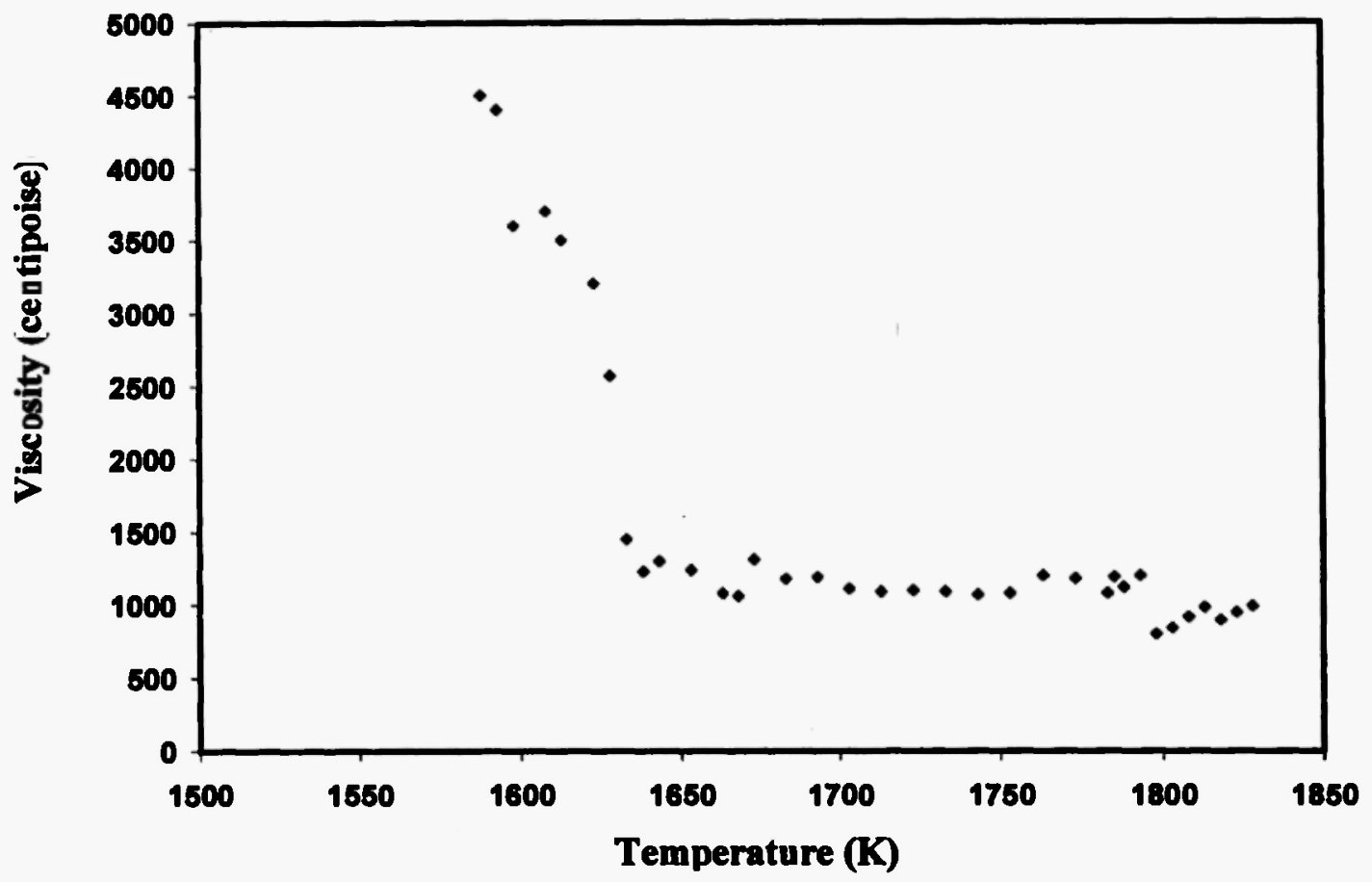

Fig. 6: Plot of apparent viscosity (cps or mYa.s) as a function of temperature (K) for experimental tundish slag. 


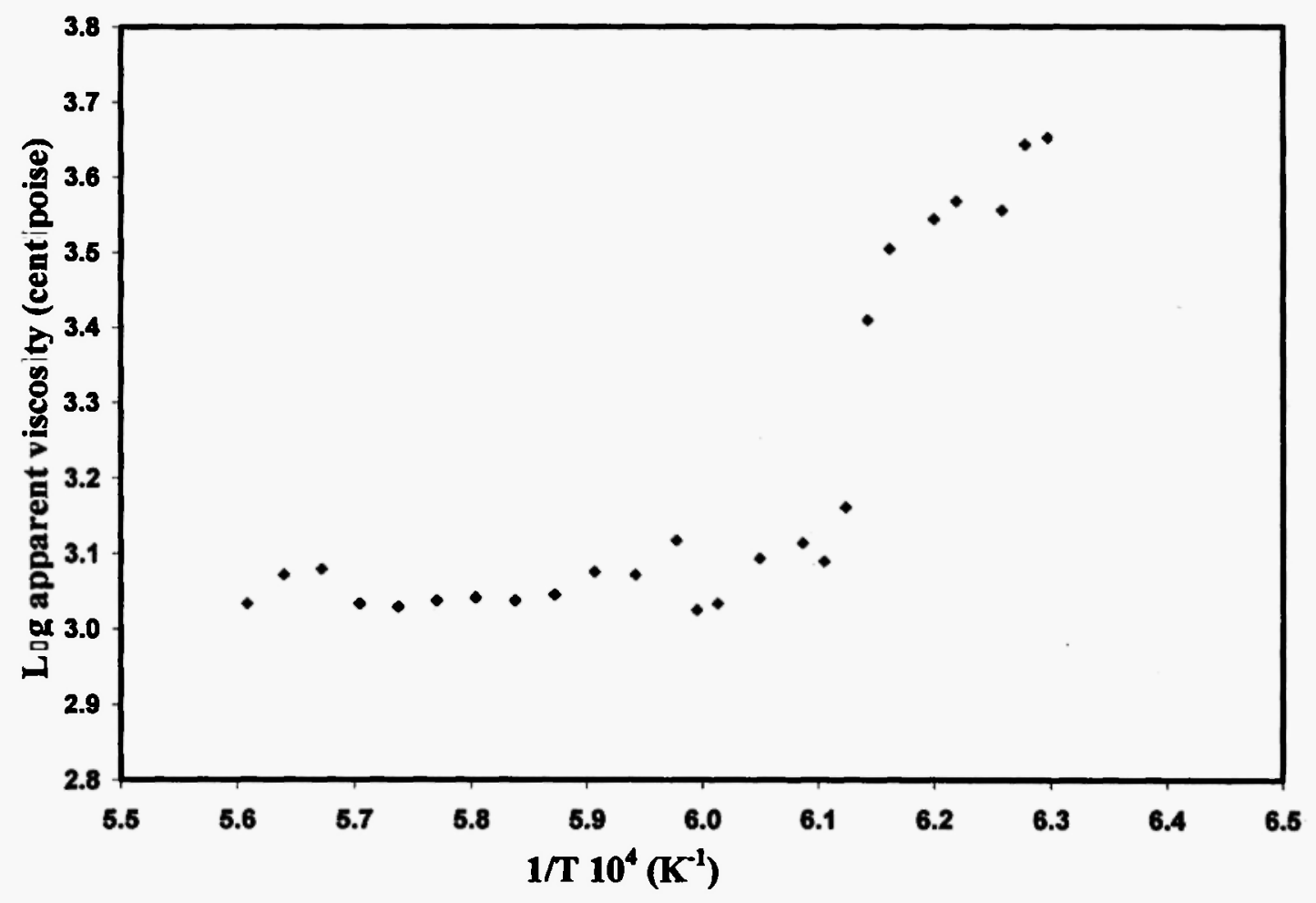

Fig. 7: Plot of log apparent viscosity (cps or $\mathrm{mPa} . \mathrm{s}$ ) as a function of reciprocal temperature (K) for experimental tundish slag.

would have been near solidification (points D,C respectively, Table 5). Therefore the gel point noted from the rheological test work for this slag $(\sim 1673 \mathrm{~K}$, Figure 5) is reasonable based on the solidification points for the components found. Interestingly this slag composition has been reported to lead to good castability $/ 14 /$, with small aluminum addition and "modest" Ca treatment. It is important to note that whereas the experimental slag did not contain alumina as prepared, the melt was held in an alumina crucible, thereby providing a source for the alumina noted.

Perhaps equally important for this experimental slag is the presence of a defined solidification temperature. Although well below ladle temperatures this would have the potential to create operation difficulties should there be a stoppage or severe slowdown in the sequence of a heat of steel from ladle, through tundish to caster, such as that caused by clogging.

For the industrial melts given in Table 3 the presence of larnite $\left(2 \mathrm{CaO} . \mathrm{SiO}_{2}\right)$, hibonite $\left(6 \mathrm{Al}_{2} \mathrm{O}_{3} \cdot \mathrm{CaO}\right)$ and a glass is noted. The glass is similar to that reported for the laboratory slag (mpt $\sim 1950 \mathrm{~K}$ ) and the minerals are represented in the CAS system similar to gehlenite $\left(2 \mathrm{CaO} \cdot \mathrm{Al}_{2} \mathrm{O}_{3} \cdot \mathrm{SiO}_{2}\right)$ found in the experimental slag. Therefore it is suggested that this composition of ladle slag should not lead to formation of accretions or clogging.

In contrast, the experimental tundish slags were generally amorphous, both from lack of defined mineral occurrences (Table 5) and from rheological behaviour (Figures 6,7). Although the predominant glass phase has a solidification temperature well below steelmaking temperatures and so should therefore be liquid the chemical reactivity with $\mathrm{MgO}$ and to a lesser extent $\mathrm{ZrO}_{2}$ as a result of the high $\mathrm{MnO}$ content is significant. For example, the presence of $3.5 \mathrm{wt} \% \mathrm{CaO}$ in the experimental tundish slag is due to $\mathrm{CaO}$ being removed from the $\mathrm{CaO}$-stabilised $\mathrm{ZrO}_{2}$ crucible that contained the melt. As noted by Tuttle et al. /15/ this is a major drawback to using calcium zirconate as a nozzle refractory in that the $\mathrm{CaO}$ released is free to react with any alumina present to form calcium aluminates. 
Whereas the ideal calcium aluminate, about $50 \%$ by weight of each of $\mathrm{CaO}$ and $\mathrm{Al}_{2} \mathrm{O}_{3}$, melts at $1688 \mathrm{~K}$ and is commonly used as a flux, the binary phase diagram /13/ clearly shows that significant increases in refractorieness occurs for aluminates more rich or poor in lime.

Interestingly, the zirconia grains (point $\mathrm{K}$, Table 5) were also noted and discussed by Tuttle et al. /15/ as being expected from thermodynamic predictions. Therefore, although $\mathrm{ZrO}_{2}$ may be attractive as a nozzle material the presence of $\mathrm{CaO}$ and free $\mathrm{ZrO}_{2}$ liberated into the melt would tend to enhance the formation of refractory minerals that in turn could form the accretions that lead to clogging.

When considering the mineralogy of the accretions that formed on an alumina plate (Table 4) it is apparent that clogging is inevitable. Although some gehlenite was found the predominant minerals were hibonite, mullite and spinel, all of which are solid at steelmaking temperatures. Therefore the use of alumina would not seem to be an attractive solution when deciding on an appropriate nozzle/gating system refractory material.

Referring to the performance of $\mathrm{MgO}$ in the static crucible tundish tests it is evident that the high $\mathrm{MnO}$ tundish slag does react with $\mathrm{MgO}$ at the slag/crucible interface (Table 5, points F, G). However, no evidence of periclase was found in the slag suggesting that a $\mathrm{MgO}$-based material may be superior to stabilised $\mathrm{ZrO}_{2}$, especially since $\mathrm{MgO}$-based refractories are often used as tundish linings. The obvious drawback to this is the possible formation of a $\mathrm{MgO}-\mathrm{Al}_{2} \mathrm{O}_{3}$ spinel. However, it is suggested that careful control of the $\mathrm{CaO}$ level as previously noted should minimise the problem.

Finally, the presence of the refractory minerals larnite and hibonite in the industrial ladle slags poses a concern regarding slag carry-over, ladle to tundish. Although these minerals were not found in the tundish slag in the present work they were present in the previous work cited /11/. As seen in Table 1 this latter tundish slag had a much lower $\mathrm{MnO}$ content than that of the present work (13.4 vs. about 33 mass \% respectively). Therefore, the effect of slag carry-over into tundish may be less critical for situations where the tundish slag is relatively amorphous. For other situations, the use of a material such as the feldspathoid nepheline syenite referred to in previous works $/ 7-9 /$ as part of a flux mixture should be beneficial in that a suite of low-melting point minerals such as pseudowollastonite and merwinite was found to replace the more refractory mineralogy.

\section{CONCLUSIONS}

1. The cause and prevention of nozzle clogging are mineralogically complex and are a function of ladle and tundish slag composition as well as composition of nozzle/gating assembly.

2. Based on the present work it is suggested that a $\mathrm{MgO}$-based refractory material such as $\mathrm{MgO}-\mathrm{Al}_{2} \mathrm{O}_{3}$ spinel would be superior to either $\mathrm{Al}_{2} \mathrm{O}_{3}$ or $\mathrm{CaO}$ stabilised $\mathrm{ZrO}_{2}$ as a nozzle refractory material.

3. Ladle slags often contain refractory minerals that form from a variety of sources including, but not restricted to, deoxidisers such as $\mathrm{Al}$ and $\mathrm{Si}$. Therefore the amount of slag carried over from ladle to tundish may enhance clogging.

4. Because clogging results from the formation of refractory minerals on the nozzle/gating system more basic (higher lime) tundish slags may be more susceptible to clogging than amorphous slags such as those with high levels of $\mathrm{MnO}$.

5. The addition of a feldspathoid material such as nepheline syenite as part of a flux mixture to a high lime tundish slag may serve to reduce the rate of accretion formation.

\section{ACKNOWLEDGEMENTS}

The author wishes to acknowledge financial assistance received from the Natural Sciences and Engineering Research Council of Canada. As well, the technical assistance of Mr. C. Prest, Ms. N. Jacobi and Mr. D. Weisgerber is gratefully acknowledged.

\section{REFERENCES}

1. S. Ramachandran, K. Peaslec and J.D. Smith, Steelmaking Conference Proceedings, ISS, Warrendale, Pa, USA, (2001), p.729-734. 
2. E. Fuhr, C. Cicutti, G. Walter and G. Torga: ISS Trans., 30(12), 53-58 (2003).

3. N.K. Das, N. Sen, M. Ghosh and R. Sau, Scandinavian J.of Metallurgy, 34, 276-282 (2005).

4. Y.H. Park and D.S. Kim, Metallurgical and Materials Transactions B, 36B, 495-502 (2005).

5. B.-H. Yoon, K.-H. Heo, J.-S. Kim and H.-S. Sohn, Ironmaking and Steelmaking, 29(3), 215-218 (2002).

6. J. L. Lagerberg, W.W. Oldenburg, R.S. Huisman, J, Yardy and M. Kendall, MPT. International, 5, 44-47 (2005).

7. T.S. Tribe, P.W. Kingston and W.F. Caley, Canadian Metallurgical Quarterly, 36 (2), 95-101 (1997).

8. J.R. MacLean, P.W. Kingston, J.B. MacDonald and W.F. Caley, Ironmaking and Steelmaking, 24(5), 406-411 (1997).
9. T.S. Tribe, P.W. Kingston, J.B. MacDonald and W.F. Caley, Ironmaking and Steelmaking, 21(2), 145-149 (1994).

10. W.F. Caley, D. Weisgerber and G.J. Kipouros: AISTech, 1, 783-795 (2004).

11. W.F. Caley and J.B. MacDonald, Ironmaking and Steelmaking, 28(2), 96-100 (2001).

12. W.F. Caley, C. Prest, J.B. MacDonald and S.G. Whiteway, Canadian Metallurgical Quarterly, 41 (2), 205-212 (2002).

13. Phase Diagrams for Ceramists, American Ceramic Society, Columbus, Ohio, USA, (1964).

14. K. Ahlborg, Steelmaking Conference Proceedings, ISS, Warrendale, Pa., USA, (2001), p.861-869.

15. R.B. Tuttle, J.D. Smith and K.D. Peaslee, Metallurgical and Materials Transactions $B, 36 \mathrm{~B}$, 885-892 (2005). 